\title{
Urban planning roles in responding to food security needs
}

\author{
Christine Slade ${ }^{a} *$ and Claudia Baldwin ${ }^{\text {a }}$ \\ University of the Sunshine Coast \\ Trevor Budge $b$ \\ La Trobe University
}

\begin{abstract}
Submitted February 13, 2016 / Revised July 6 and July 26, 2016 / Accepted July 27, 2016 /
Published online November 29, 2016

Citation: Slade, C., Baldwin, C., \& Budge, T. (2016). Urban planning roles in responding to food security needs. Journal of Agriculture, Food Systems, and Community Development, 7(1), 33-48. http://dx.doi.org/10.5304/jafscd.2016.071.005
\end{abstract}

Copyright (C) 2016 by New Leaf Associates, Inc.

\begin{abstract}
Food security is a daily problem for vulnerable groups of urban citizens in developed countries, who face physical and mental stress and poor health outcomes from limited food choices. They are often unable to change their circumstances through the marginalizing impacts of urban planning policy, regulation, and infrastructure barriers. Local government is often confronted with these impacts and absorbs the responsibility to act "on the ground" in the absence of a coordinated, multilevel institutional response. Health professionals and local government urban planners increasingly collaborate to examine the design of cities and towns to improve food security. Despite increased awareness and the inclusion of food security in some planning strategies, regulation, and decision-making, results
\end{abstract}

${ }^{\text {a }}$ School of Social Sciences, University of the Sunshine Coast, Queensland, Australia.

${ }^{\mathrm{b}}$ Community Planning \& Development Program, La Trobe University, Bendigo, Victoria, Australia.

* Corresponding author: Christine Slade, c.slade@uq.edu.au are limited in many jurisdictions. This research uses a case study methodology to gain insights into the systemic barriers facing local government planners in the state of Victoria, Australia, in responding to municipal food security challenges. Four foodrelated themes drawn from the data show that both internal systemic barriers and an external lack of fit with federal and state governments blur the understanding of food security challenges and limit planning solutions. Local government planners need consistent legislative and planning scheme priorities, combined with strengthened regulatory tools, to address food security more effectively. Increased feedback opportunities for local government staff to share their valuable experience and knowledge with higher levels of government would allow for a more coordinated approach to addressing this multijurisdictional problem.

\section{Keywords}

Food Access; Food Desert; Food Policy; Food Security; Land Use Planning; Local Government; Planning and Infrastructure Barriers; Urban Agriculture 


\section{Introduction}

Food security, defined at its simplest as having enough to eat, is a recurrent challenge for most of the world's population. Even in developed countries with rising affluence, robust public transport, and sophisticated refrigeration and distribution systems, consistent and affordable access to nutritious food is a daily problem for vulnerable urban populations (Rosin, Stock \& Campbell, 2012). At-risk groups include the unemployed and underemployed; low-income earners; single parents; the elderly; the homeless; people with disabilities, mental illnesses, and/or addictions; indigenous Australians; and people from non-English speaking backgrounds (Booth \& Smith, 2001; VicHealth, 2005, 2011). Lack of food security can affect an individual's health status, both physically and mentally, due to stress, anxiety, social disruptions, reduced nutrition intake, and potential eating irregularities (Booth \& Smith, 2001). In Australia, diet-related illness, such as diabetes linked to obesity and low levels of exercise, is a significant contributor to disability and death, and is on the rise (Australian Institute of Health and Welfare [AIHW], 2012).

Rates of obesity are higher among those with lower incomes (Cummins \& Macintyre, 2005; Levine, 2011), yet people with limited incomes tend to buy bulky, poor quality foods that have little nutritional value but have an oversupply of energy, fats, and sugars, in order to curb their hunger (Burns, 2004). Vulnerable people face physical and mental stress and poor health outcomes from limited food choices, yet are often unable to change their circumstances.

As early as 1995 a single-item question in the Australian National Nutrition Survey revealed that over the previous 12 months, $5.2 \%$ of persons over the age of 19 were unable to replenish food supplies when they ran out. In 2011, a smaller survey, with results weighted to a national representation, found $8 \%$ of respondents ran out of food and could not afford to buy any more (Lockie \& Pietsch, 2012). A comparison survey using both a single-item measure and the comprehensive U.S. Household Food Security Survey Module in three Australian disadvantaged municipalities found significantly higher numbers of people unable to access healthy, affordable food on a regular basis, with results of $15.8 \%$ and $21.9 \%$, respectively (Nolan, Rikard-Bell, Mohsin \& Williams, 2006). Data from the Victorian Population Survey and Community Indicators highlight that residents in 59 out of 73 local government areas in the state were facing food security challenges (VicHealth, 2008). The results of these surveys demonstrate that food security challenges are significant for increasing numbers of at-risk individuals across many municipalities.

With excessive reliance on personal transport in cities and towns, those reliant on low-cost public transport to access outlets for fresh, nutritious food can find themselves marginalized (Parham, 2007). Communities are often confronted with the stark consequences of the situation, evidenced by inequitable access in "food desert" neighborhoods in the United Kingdom and the United States (Beer, 2013), as well as in Australia. While this should be of concern to all levels of government, in the absence of a coordinated multilevel institutional approach among the state and federal levels of Australian government, ${ }^{1}$ responsibility and leadership often default to local governments, which feel direct pressure from their communities (Slade, 2013; Yeatman, 2009). As a result, some Australian councils try to absorb food security aspects into their planning, policy, and practice.

While local governments' initial efforts focused on ensuring food availability and distribution, increasing focus has been turned to underlying systemic issues, such as inadequate public transport and infrastructure, regulatory inhibitors for land use, and deficient policy development (Desjardins, Lubczynski, \& Xuereb, 2011; Slade, 2013; Sonnino, 2009). Health professionals and urban planners are increasingly collaborating to tackle food security challenges. Moving beyond the health agenda of nutrition, healthy food choices, and education programs, they examine ways to improve the rigor in

\footnotetext{
${ }^{1}$ In order to understand capacity, it is important to know that local government is not recognized in the Australian federal constitution but is given power through Local Government Acts in each state (including Victoria, in this research) and territory. Therefore, expectations and roles of local government shift through legislative changes, causing it to be in a continuous state of change and only able to practice with limited power devolved by the states (Aulich, 2005).
} 
food outlet decision-making influenced by planners and look at whether legislation, statutory planning provisions, and urban design policies and guidelines can be used effectively to improve food security. To date, integrating health outcomes, and the larger issue of food security, into the Australian planning and local government mainstream is uneven (Budge \& Slade, 2009). Despite greater general awareness and the inclusion of these issues in some planning strategies, regulation, and decision-making, positive outcomes in many jurisdictions are still limited.

Urban planning is "inherently a governance activity, situated in a complex landscape" of government, community and private organizations (Healey, 2005, p. 304). Methods for achieving food security are complex and cross-jurisdictional, with limited guidelines and regulatory mechanisms for incorporation and implementation (MacRae, 2011; Mendes, 2008). This article focuses on local government's strategic and statutory planning roles in responding to food security challenges, but we recognize that in federal systems such as in North America and Australia, these roles are inextricably linked to federal and state government policy and planning legislation and regulations to varying degrees.

We argue that systemic urban planning barriers that limit food security are overlooked in daily local government practice, and even when understood are difficult to address at the local level, due to the complexity of jurisdictional relationships involved. We present case studies from two state-level health promotion programs that partnered with 12 local governments to explore the following research questions:

1. How can urban planning roles and responsibilities respond to food security challenges?

2. What enablers and barriers do local government urban planners face in seeking to improve food security in their municipalities?

We begin by briefly discussing the roles of urban planning in relation to food security at a local government level, then introduce our research context, methodology, methods of data collection and analysis, followed by the results, barriers, and enablers of urban planning in responding to food security challenges. Finally, we summarize the main points, limitations, and future research possibilities.

\section{Potential for Urban Planning to Address Food Security}

Urban planning links health outcomes and place at a local level. Links between health and place are not new but have shifted over time from solely a medical model of individual health outcomes to include social, economic, and environmental features that may pose higher health risks and inequality for people in certain locations (Smith \& Easterlow, 2005). This emphasis on a social model of health shifts responsibility for response from individuals to government institutions, organizations, and systems (Smith \& Easterlow, 2005). Urban planning is a key activity in the development of healthy places because ideally it can provide sustainable and equitable access to healthy food across the built environment (Morgan, 2009).

According to Pothukuchi and Kaufman (2000, p. 113), urban planners are involved in "land use, housing, transportation, the environment, and the economy ... [and] more recently, the health, education and energy systems," yet interest in food security has been slower. These authors surveyed planning departments in 22 areas of the U.S. in 1997 and found that interest in local food system issues was limited for various reasons. These included lack of linkage with the built environment; it being seen as a rural issue; the view that the food system belongs to the private sector; no knowledge of funding programs; the food system is fine as it is; there are limited opportunities for collaboration; and lack of understanding of the issues. More recently, Cassidy and Patterson (2008) added that there is a perception that food security is not part of a planner's expertise; food choices are a private matter; and planners think there is nothing they can do. Within the context of urban agriculture as a planning responsibility, Thibert (2012) points out that local government urban planners are illequipped, both in practice and a policy context, to implement initiatives. While Clancy (2004) suggests that food advocates need to convince planners of 
the benefits of such involvement, the challenges for urban planners in Australian local government are more systemic and considered beyond their control to change. An Australian study by Allender et al. (2009) found that local governments can feel powerless to make a change, with hesitation on their part to increase regulation in what is seen as an already heavily regulated system. There is evidence of multiple barriers to urban planning to address complex challenges such as food security.

Three key interfaces between urban planning and improving food security outcomes are strategic planning and policy development, land use regulation, and infrastructure development. For example, urban planning can influence the location and establishment of urban agriculture (UA) activities, such as community gardens and fresh food stalls. These activities provide economic and social benefits, such as productive use of vacant spaces, livability in neighborhoods, poverty alleviation, and improved health outcomes (Mougeot, 2006; Thompson, Corkery, \& Judd, 2007; Wheeler, 2004). UA requires appropriate zoning and design guidelines in local government planning schemes in order to be successful (Castillo, Winkle, Krauss, Turkewitz, Silva, \& Heinemann, 2013; Wheeler, 2004). Yet there is little support in Australian planning policy for UA introduction (Pires \& Burton, 2013). This differs from other locations such as the City of Waterloo, Canada, which clearly outlines UA guidelines in its local Official Plan (Port \& Moos, 2014) and in Dar es Salaam, Tanzania, where UA has a specific land zoning category as a valued source of food security (Halloran \& Magid, 2013). In Australia, statutory mechanisms such as planning schemes that substantially influence decision-making are based on state legislation. As a result, government support of UA through appropriate institutional frameworks from national to local levels is needed (Girardet, 2004).

Places with limited healthy food outlets and insufficient transport or walking options are called "food deserts" because of their limited access to healthy foods and easy access to fast food, convenience shops, and liquor outlets (Parham, 2007). Empirical studies across countries, such as the United Kingdom and Australia, differ in their findings about the existence of food deserts (see Ball,
Timperio \& Crawford, 2009; Cummins \& Macintyre 1999; Donkin, Dowler, Stevenson, \& Turner, 1999; Guy, Clarke \& Eyre, 2004; Turrell, Blakely, Patterson, \& Oldenburg, 2004; Winkler, Turrell, \& Patterson, 2006). Of note is that the link between access to food and neighborhood disadvantage varies according to indicators used. Recent literature recognizes these differences and discusses ways of improving the rigor and scope of measurement tools used in the future (see Caspi, Sorensen, Subramanian, \& Kawachi, 2012; Ding \& Gebel, 2012; Kelly, Flood, \& Yeatman, 2011). Nevertheless, the differing study results highlight the complexity and variability of inequitable food access determinants and the potential challenges for local government urban planners to respond effectively.

Urban planners can also contribute to and benefit from geographic information system (GIS) mapping undertaken by local government to visually display the relationship between the location of food outlets and public transport, cycling, and/or walking access. The purpose of highlighting the GIS food desert mapping undertaken by local governments in this research is to provide insights into the systemic planning and infrastructure problems that limit food access, rather than to suggest opening new supermarkets within such locations, as has been a common practice in the U.S. (Shannon, 2014). The local governments involved here also investigated other factors involved in inequitable access, in line with recent research into pricing (see Alkon, Block, Moore, Gillis, DiNuccio \& Chavez, 2013), and marketing and consumer behavior (Ghosh-Dastidar et al., 2014).

As food security is linked with sustainability and health concerns, interest is growing across local government to address this challenge through policy development. Policies should be concerned not only about what people eat (Lang, Barling, \& Caraher, 2001), but also how food is produced and how equitable distribution and consumption are. Local government has an influential role in food policy development to increase the longevity of positive food security outcomes. For example, the development of the London Food Strategy (see Reynolds, 2009) was based on a holistic view of urban food systems that can embrace the diverse and numerous stakeholder groups in food issues 
(Mansfield \& Mendes, 2013). However, to be most effective, federal, state, and local government need to have consistent food-related policies in place (Slade \& Wardell-Johnson, 2016) that account for current externalities in the food system, develop a broader understanding of food beyond commodification, and increase support for health promotion (MacRae, 2011). Land use policies are particularly important in facilitating healthy built environments that include food supply and equitable access. A fragmented, silo approach to food policy development often leads to inconsistencies, overlap, and gaps (Department of Agriculture, Fisheries and Forestry [DAFF], 2011). As a result, food problems are not addressed in an integrated and coordinated way by government, resulting in policy decisions made at one level or in one area having significant ramifications in other food security areas (Prime Minister's Science, Engineering and Innovation Council [PMSEIC], 2010).

Thus previous research suggests that urban planning at a local government level plays an important role in advancing municipal food security, particularly in identifying patterns of inequitable access, facilitating urban food supply, and embedding food security principles into policies and plans. This role would be enhanced significantly through integrated, consistent, and enabling food security related policies, regulations, and practices at federal and state government levels.

\section{Research Context and Methodology}

This research uses a case study approach to understand the lessons learned from two health promotion programs that aimed to improve food security in municipalities with high levels of socioeconomic disadvantage in the state of Victoria, Australia. The two state-government-initiated programs were, firstly, the Victorian Health Promotion Foundation's (VicHealth) Food For All program (2005-2010), working with nine local government councils (referred to as CS1); and secondly, the Victorian Department of Health's Food Security and Access Policy Development project (20092011), working with three local government councils (referred to as CS2). The goals of the pioneering Food For All program were to "reduce local government systemic and infrastructure barriers to food security" and "increase regular access to and consumption of a variety of foods in particular fruit and vegetables by people living in disadvantaged communities" (VicHealth, 2011, p. 5). The main aims of the Food Access and Food Security Policy Development project were to strengthen local government leadership and develop individualized local government food policies and/or strategies in the participating councils (Department of Human Services, North \& West Metropolitan Region, 2008).

A case study methodology enables the capture of in-depth detail of the in-situ reality of everyday life (Sarantakos, 2005) and provides opportunity to explore why particular outcomes may occur (Walter, 2006). This approach is particularly useful when the boundaries of the research and the broader contextual societal influences are blurred (Sarantakos, 2005; Stake, 2008; Yin, 2003). While we anticipate the lessons from this research will inform other jurisdictions, the intention of using a case study methodology is not chiefly to generalize findings (Stake, 2008) but rather to shed light on the depth and breadth of urban planning implications for the improvement of municipal food security within the chosen cases.

This research used three qualitative data collection methods in order to capture the complexity of the case examples and provide rigor through triangulation: in-depth interviews, primary document analysis, and secondary data analysis. We obtained human ethics approval. Interview participants were chosen through purposeful sampling due to their contextual knowledge and expertise of the topic at hand (Sarantakos, 2005). The researcher conducted semistructured, in-depth interviews using a set of questions as a guide. A total of 27 interviews were conducted with 25 participants (two participants were interviewed twice at different points in the project): six project managers $(\mathrm{CS} 1=2, \mathrm{CS} 2=4)$, coded as (PM); 14 local government officers (LGO) $(\mathrm{CS} 1=11, \mathrm{CS} 2=3)$; and five associated project members $(\mathrm{APM})(\mathrm{CS} 1=4, \mathrm{CS} 2=1)$. All participants except one were female. This number of participants was considered adequate to reach saturation. Interviews were audio-recorded and later transcribed. We analyzed the interview data using themes derived through iterative review, 
coding, and analysis with NVivo 8 software.

A thorough search of pertinent primary documents provided 41 key council plans and policies $(\mathrm{CS} 1=33, \mathrm{CS} 2=8)$, six state-based partner documents $(\mathrm{CS} 1=5, \mathrm{CS} 2=1)$, and three associated documents $(\mathrm{CS} 1=3, \mathrm{CS} 2=0)$ for thematic analysis. Secondary data analysis included 22 key evaluation documents composed of nine council evaluations $(\mathrm{CS} 1=3, \mathrm{CS} 2=6)$, eight lead partner reports (CS1 $=6, \mathrm{CS} 2=2)$, and five other evaluations $(\mathrm{CS} 1=5$, $\mathrm{CS} 2=0$ ). The analysis of these primary and secondary data documents through thematic coding was based on five categories, namely preservation of high quality agricultural land (AG); food access (FA); food security (FS); food supply and/or a sustainable food system (FSU); and justice and equitable access (SJ). This analysis provided empirical evidence to support interviewees' perceptions and to contextualize the case studies.

\section{Results}

Here we focus on four themes in which urban planning plays an important role: place-based inequitable food access; infrastructure barriers to food access; regulatory barriers to urban agriculture activities; and embedding food security principles in land use policies. They demonstrate the enablers and barriers that influence urban planning advances in improving municipal food security.

\section{Place-based Inequitable Food Access}

Local government used community consultation and food access GIS mapping to identify vulnerable localities and build understanding of the implications of food security challenges. While many neighborhoods had a plentiful supply of healthy food, some experienced an absence of healthy food retail outlets, a situation sometimes referred to as "food deserts." Food access mapping by the cities of Hobsons Bay and Darebin illustrate these difficulties. Hobsons Bay chose to represent healthy food by mapping bakery, butcher, or fruit and vegetable outlets within two radii of 500 meters (.31 mile) and one kilometer (.62 mile).

Figure 1 shows that the Hobsons Bay suburbs of Laverton, Altona North, Brooklyn, and parts of
Altona Meadows experience a dearth of fresh food outlets. ${ }^{2}$ According to one of the project officers, the visualization of this problem can be an excellent tool for planners to understand systemic food security barriers.

With the maps it's really quite stark when you see big chunks of the municipality where there's nothing there....It's a really good visual tool for the planners to get a sense of pictorially where the gaps are and the lack of fresh food outlets. (2LGO2)

The City of Darebin, which chose to represent healthy food by mapping green grocers and supermarkets, is another municipality with food desert areas. Comparing acceptable walking radii of 250 meters (.16 mile), 500 meters (.31 mile), and 750 meters (.47 mile), Figure 2 illustrates that significant areas in the north of the municipality have inequitable food access compared to the southern half, even within the furthest walking distance.

Zoning within a planning scheme affects the location of food outlets; however, planning cannot limit the placement or number of fast food outlets if they are within a suitably designated zone. This contributes to an oversupply of unhealthy food outlets in some neighborhoods, at the expense of healthy outlets. Several participants expressed concern with "as-of-right use," which allows developers or other businesses broad discretionary scope in choosing the type of business combinations in their projects. The power to change this situation is not within the planners' control, as explained by one project officer after discussions with land use planners:

There's so much by-right, so that they [planners] can't respond to fast food, excessive fast food, nor packaged alcohol nor gambling. As long as they are within the right sort of zoning they've by-right permits. So

\footnotetext{
${ }^{2}$ It should be noted that Seabrook in the left bottom corner of the map looks like a food desert if this map is taken in isolation, but regional mapping in the western suburbs of Melbourne has shown that there is a nearby shopping center in the adjacent municipality.
} 
Figure 1. Depiction of Food Desert Areas in City of Hobsons Bay

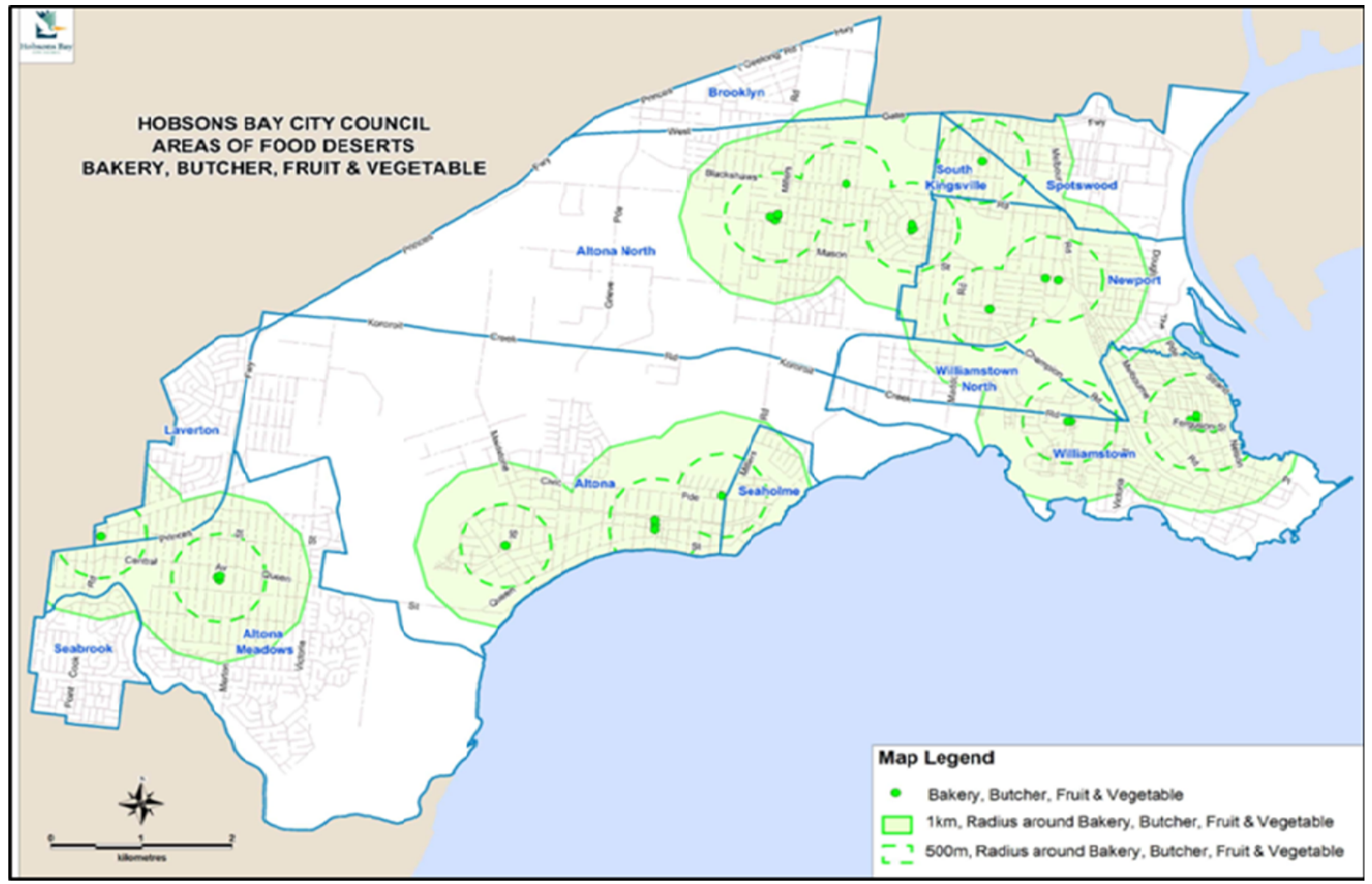

Source: Hobsons Bay City Council (2011b, p. 2).

they [planners] are saying that's where the changes need to take place. (1LGO7)

Further to the granting of as-of-right use, the definition of "retail activity" in planning schemes means "anything that sells retail" (ILGO7). Such an ambiguous definition can lead to unintended consequences that impinge on food security, as explained by one interviewee.

They [local government] have got very limited powers to dictate, to mandate or control business mix. If there is a shopping strip and five fast food outlets open they can't say "No, we want one fruit and veggie shop, one health food shop and one fast food shop." They can't do that. It's actually not allowable. So the extent to which local government can influence large scale planning initiatives is surprisingly limited. (1APM2a)
This lack of control over mix constrains the capacity to deliver on new initiatives that require a strategic land use change. Food outlets generally (and healthy food outlets particularly) do not have special considerations within the retail zone. Additionally, 14 interviewees highlighted the lack of state government policy direction and regulatory mechanisms to enable local government food security responses. Local government land use planning is dependent on overarching state government legislation and planning provisions (1LGO2a). Planners are limited in their capacity to address the systemic land use problems associated with food security. In their opinion, planning schemes need to change in order to reverse the trend of facilitating easy access between residential areas and takeaway food outlets.

I think the biggest change needs to be made... 
further up the ladder, in terms of state and federal government, where the changes around transport connections, and having residential estates that are close to food outlets, and not allowing the planning scheme...to put in rows after rows of MacDonalds and KFCs. There are lot of things that could be done to improve it but won't come from local government level because we don't have support we need from that level. (1LGO1)

This concern for limited local government authority in land use planning, regulation, decision-making was also reflected by 16 of the 27 interview participants, as exemplified by the following interviewee.

Much of the planning legislation regrettably is still running on an economic use of land model and local government really are just administrators...of the state legislation in that area, so we have very little discretion and incredibly rule bound. (1M2)

\section{Infrastructure Barriers to Food Access}

Further GIS mapping from the city of Hobsons Bay exemplifies the relationship between infrastructure barriers and food access. In the first
Figure 2. Visual Illustration of Food Desert Areas in the City of Darebin with 250, 500, and 750 Meter (.16 mile, .31 mile, and .47 mile) Buffers

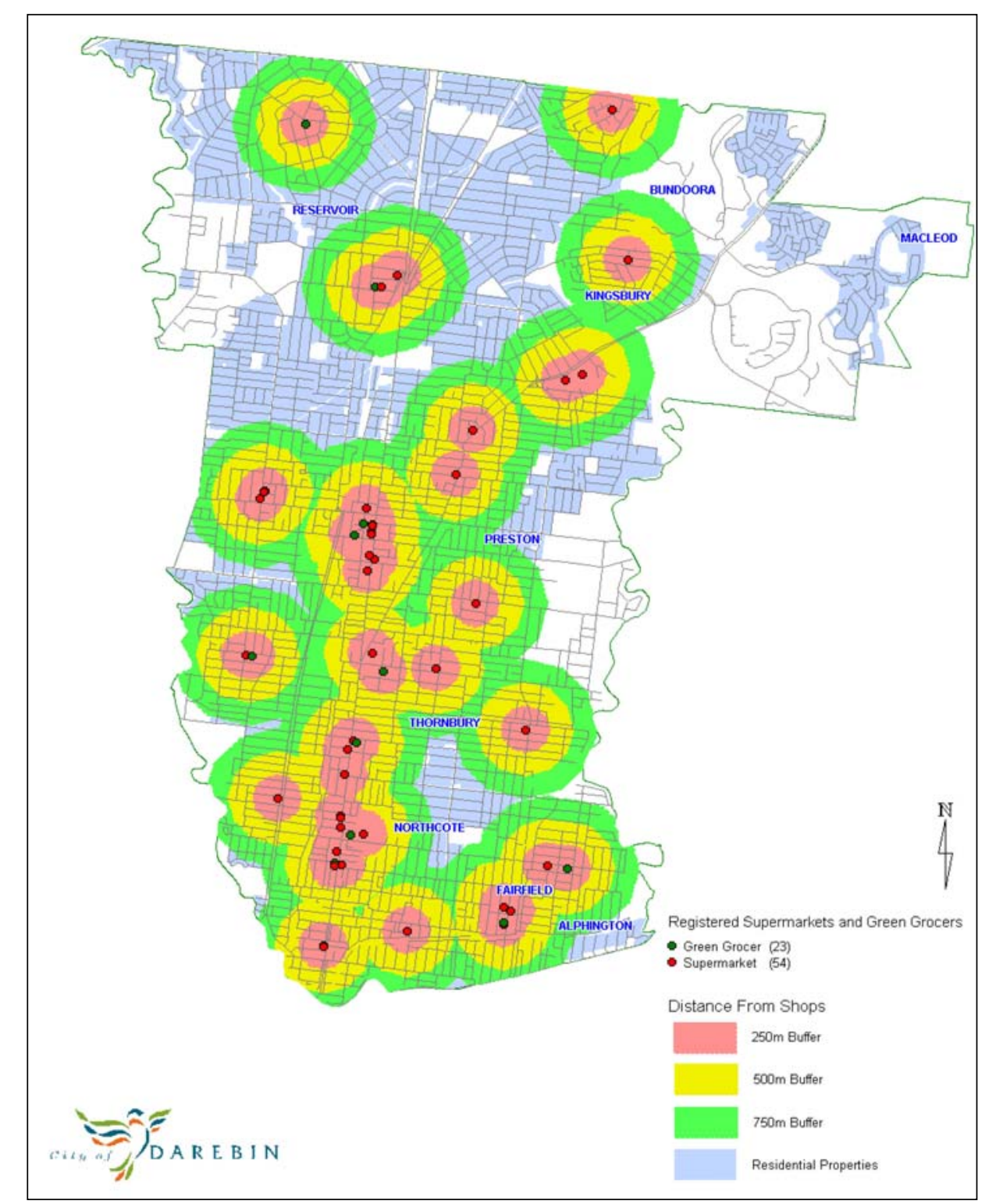

Source: City of Darebin (2008, p. 13). example, residents with mobility problems found it very difficult physically to access Altona Gate Shopping Centre, a large retail precinct with two supermarkets and other speciality shops. The orange circle in Figure 3 illustrates that the Westgate Freeway (the thin solid blue line running horizontally through the orange circle) separates the northern residential areas and the shopping center. A project officer discovered this problem when talking with residents. 


\section{Figure 3. Two Food Access Trouble Spots in Hobsons Bay for Vulnerable Residents}

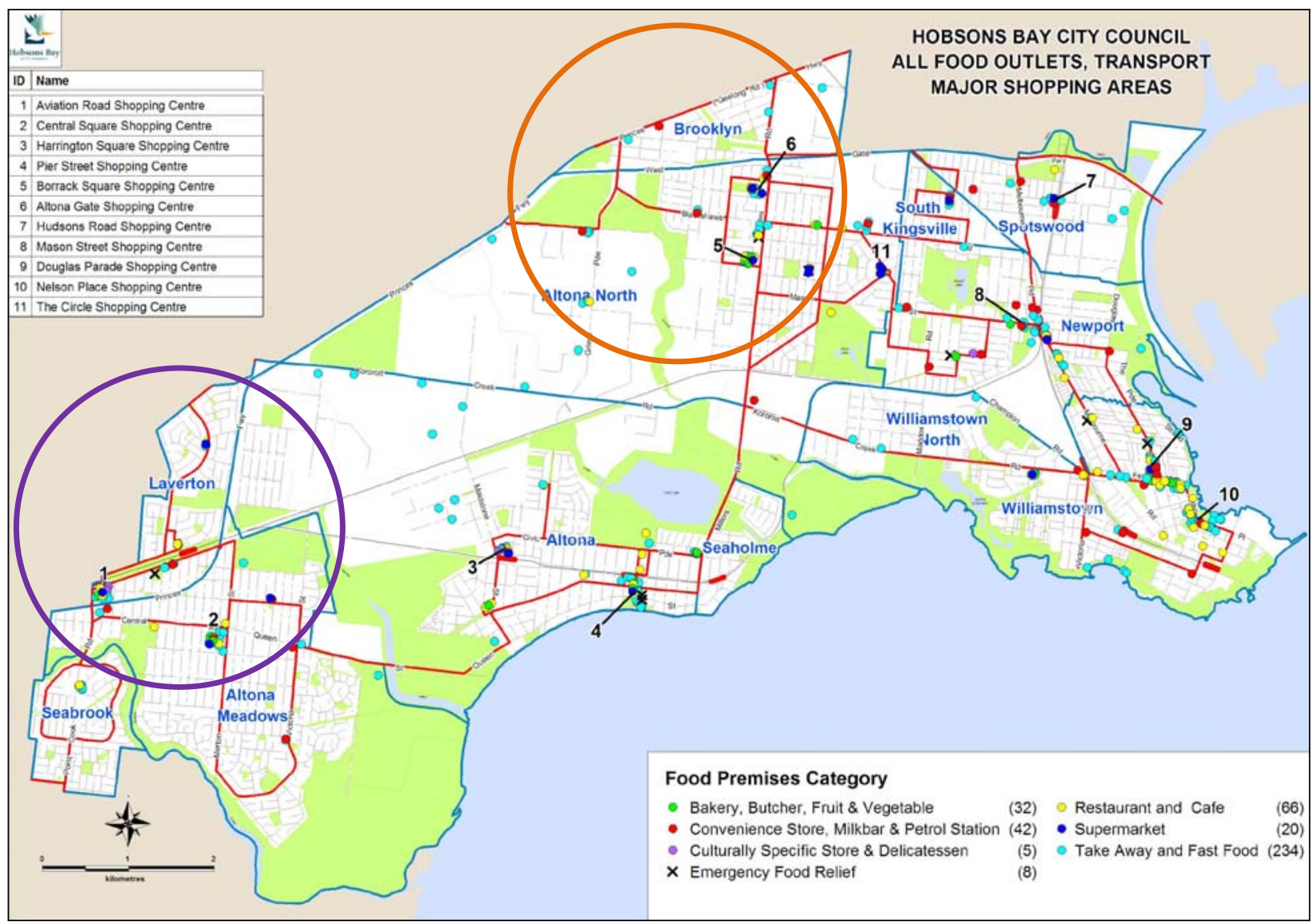

Source: Hobsons Bay City Council (2011a).

It actually looks on paper that it is quite well catered for... but however in speaking particularly to senior residents of this area, there is a Westgate freeway between a chunk of these residents and the shopping centre. So for those who don't drive and particularly these elderly residents, some of whom are on wheelie frames [walkers], actually access to that shopping centre is really very, very difficult. So even though it is only 500 metres [.31 mile] away there's a huge physical barrier and it's also really poorly designed in terms of pedestrian access. Great for cars, of course! (2LGO2)

The suburb of Laverton provides a second example where a four track (and in the future six track) railway line blocks access between the northern end of the suburb and the Aviation Road Shopping Centre on the other side of the tracks (see the purple circle in Figure 3). Parents with prams, or small children, or people with limited mobility need to negotiate the railway lines in order to access food, as explained by one interview participant:

It's the same in Laverton as well: you have the physical barrier of the railway line and most of the residents are at the northern end of Laverton, but most of the retail is on the other side of the railway line. It's not just one, it's like a four track, soon to be six track, rail line, so if you have a pram and a couple of kids you need to walk that distance and then you have to go over the railway line; it's a bit of a nightmare. (2LGO2) 
Because state governments provide railways and major freeways, these examples highlight the need for coordinated urban planning approaches between all government levels when addressing complex and multijurisdictional challenges, such as food security.

\section{Regulatory Barriers to Urban Agriculture Activities} Complex internal regulatory barriers can also slow new food security initiatives, such as increasing urban agricultural activities for community gardens, fruit trees in public spaces, home gardening, farmers markets, and food swaps. Uses of urban land, such as community gardens and orchards, require a review of "land use, open space and building regulations and practice" (VicHealth, 2010, p. 1) to adjust existing structures and procedures to accommodate new options. Three participants expressed frustration about the regulatory processes involved in developing community gardens, either as part of a council project or in response to community requests, as illustrated by one local government project officer:

They [community gardens]... sound so simple but they are not. It is hard work. They are not as simple as "Here's a piece of ground, go for it." There are so many regulations it's amazing. (1LGO10)

In one municipality the council initiated a community garden with several stakeholders from state and local government jurisdictions. Bureaucratic processes held up the progress of the project, which required a memorandum of understanding, a lease agreement, public liability insurance, allocating maintenance responsibilities, and a grant application. The project officer shared some of the frustration about the time taken to open the community facility:

We are chomping at the bit but we can't until we get the permission, the lease agreement from the Department of Human Services. We can't put a fence up and I think defining the area with a fence, even though it is not going to be a big, high fence [is important]...Then we can really say "Here's the garden." So until then we're kind of dabbling around the edges...So we are getting there but these things take time. (1LGO3)

Consequently, systemic regulatory bureaucratic processes hinder local government capacity to deliver food security options in a timely way.

Establishing community gardens was not the only initiative that found the regulatory process inhibiting. In another council, a local municipal law thwarted a food security initiative by preventing the setting up of a mobile fruit and vegetable stall on council land unless a permit was granted for each site. The cost of the permit and the limitations on locations were obstacles to potential small-scale fruit and vegetable vendors, as an interviewee explained:

It [the permit] was $\$ 500$ per site and they can't set up within 500 metres of a school or an established community centre as well. I don't know whether that was from a traffic point of view but you want to be based at a community centre, you want to be based at a school... so I am trying to work with the person involved in reviewing these other local laws. (1LGO2a)

It can take considerable time and be a lengthy process to review and possibly change these local laws. In the meantime, local government capacity to respond effectively to food security challenges is limited.

\section{Embedding Food Security Principles in Land Use Policies}

Both partnership projects envisaged the inclusion of food security principles in the most influential council policies and plans as an essential way to ensure local government's capacity to address municipal food security problems. Councils achieved the most policy development success in the mandated Council Plans and Municipal Health and Wellbeing Plans required in the state of Victoria. The majority of interview participants who were directly involved with their municipal planning departments stated, however, that the local government's key land use policy document, 
the Municipal Strategic Statement (MSS), ${ }^{3}$ proved the most difficult because of its regulatory nature. Food security rhetoric presented in the MSS does not always follow through with action unless it can be translated into land use planning instruments. Local government's capacity to address systemic food security barriers through the MSS continues to be limited until state government makes changes to existing planning legislation and associated regulations, as explained by one project officer:

Most MSSs have some motherhood statement but then the actual tools that they have to enact that is the question. So it usually comes through "liveability" or things like that, you know, that they manage to have walkable neighbourhoods and easy accessibility but they can't do anything about what is a retail area. (1LGO7)

As mentioned above, one forward option is to link food security to the accepted concept of "liveability," with its associated "accessibility" and "walkability" features, which is an important aspect of the built environment and healthy outcomes planning discourse (1APM2a). Wodonga City Council uses these concepts throughout its planning policies, including its MSS, and sees the principles of food security fit nicely into this "livable neighborhood" concept.

This is where the principles of food security, planning for food security in the physical environment, such as connected neighbourhoods, and small neighbourhood shops, and public open space and community hubs, and all those kinds of things, are included in the MSS. I think that's why people who are really focused on a single agenda, like food security, want to see the words "food security" in the MSS and...I think it is probably more strategic to

\footnotetext{
3 The state's Planning and Environment Act requires all councils to prepare a Municipal Strategic Statement (MSS), aligned with Victorian state planning objectives. These outline local strategic land use and development objectives and their relationship to statutory planning scheme controls.
}

have the principles of food security in there. (1LGO3)

This point of view is easily understood: food access is a basic need that can be facilitated by the built environment. Yet there is a difference of opinion among urban planners and other interested parties in councils as to whether food security can be included legitimately in the planning framework. The most common view holds that there is no provision in the Victorian Planning and Environment Act ${ }^{4}$ to take food security problems (or other health considerations) into account, while "walkability" and "accessibility" are linked to planning codes that could be changed. This situation is further explained by an interview participant:

Accessibility has always actually been there. How can you interpret accessibility? It could mean that everybody can drive to the supermarket. In some people's heads that is what it does mean, but accessibility means something different to the people who are conscious of the needs of people who don't have cars, who can't drive, or who are disabled. So accessibility has a hook within the planning framework in Victoria on which to hang things like walkability. In the major planning documents it is not about physical activity and health; it is about walking and cycling and accessibility, which is code for physical activity. We don't have the codes for healthy eating. And there is nothing in the planning framework, and by that I mean the legislation and the planning principles, that actually enshrine that and drive it. (1APM2a)

Councils that make decisions based on food security's inclusion in land use planning schemes risk the possibility of expensive appeals by interested parties before the Victorian Civil Authority Tribunal (VCAT). Most councils are not prepared to take the issue this far because of lack of supportive state legislation, as one interviewee explains:

\footnotetext{
${ }^{4}$ This act is the key piece of state legislation that shapes local government's land use planning activities.
} 
We will just go to VCAT and get toppled because there is nothing in the Planning and Environment Act to support any of these actions you might want to put in. (1LGO7)

These examples demonstrate the limitations of planning to address food security challenges because of systemic planning, infrastructure and regulatory barriers, and the difficulty of embedding food security principles in the major land use policy documents. The lack of consistency between federal, state, and local government approaches to food security compound the impact of these limitations at the municipal level.

\section{Implications for Local Government Urban Planning}

The need for improved food security in municipalities remains a challenge; however, it has no jurisdictional home or previous regulatory exemplar to follow (Mendes, 2008). Local government, as the government level closest to the community, can play a vital role in responding to food security concerns. Links between hunger, obesity, and place are drawing increased attention to food security issues. Urban planning at a local government level can influence outcomes in creating healthy and food secure places (Morgan, 2009), and yet this influence can be limited due to legislative, regulatory, and policy barriers. This contemporary and complex challenge necessitates a whole-ofgovernment response with "joined up" (MacRae, 2011) policies and planning between federal, state, and local government to enable effective food security outcomes.

The four food security themes explored in this research draw attention to internal and external enablers and barriers facing urban planning at a local government level. The first theme provides evidence of systemic factors related to zoning that result in the inequitable access to healthy food in food desert locations. The inability of local government to control business mix together with a weak definition of "retail activity" dilute its ability to promote healthy food retail choices through planning, and points to policy deficiencies at a state government level. Similarly, the second theme of physical infrastructure barriers, such as freeways, railway tracks (often provided by other levels of government), and lack of pedestrian access provides new insights into how uncoordinated planning across federal, state, and local governments limits vulnerable individuals' access to food sources.

The introduction of urban agriculture (UA) provides economic and social benefits to a municipality (Thompson et al., 2007) through activities such as community gardens, mobile food stalls, and markets. This third theme demonstrates that lengthy and complex bureaucratic processes and restrictive municipal bylaws can inhibit these activities. Local government can address many of these restrictions through targeted policy development and planning and the refinement of local bylaws and procedures. Other barriers to increased UA activities, such as infill UA on vacant land, are more challenging for local government to address and often require cooperative responses with the landowner. Wheeler (2004) suggests that local governments should use zoning to permit urban agriculture (UA) in existing open space, but in Victoria (as in other Australian states) the scope of planning schemes is derived from state government, with scheme approval at the state level. Currently, no zones specifically enable UA in Victoria.

The fourth theme is even more complex. Municipal planners in Victoria lack regulatory planning tools to effectively address food security challenges in land use decisions (Budge \& Slade, 2009). There is no provision in the State's Planning \& Environment Act 1987 to trigger concern about food security issues. While some pioneering councils may consider using a VCAT challenge to obtain precedents for further food security initiatives, the risks are high that such an action will be unsuccessful, leaving a council with the expense of defeat. The major limitations here occur at the state government level and the lack of consistency between state and local planning regulation.

Food security challenges cross departmental and organizational boundaries and require a holistic and multipartnered approach between all levels of government. Current feedback loops for advocating changes to federal and state government policy remain ineffective, with the result that higher government levels miss the opportunity to align their 
responses based on informed community practice. This research suggests that better interchanges between multiple levels of government and feedback from local experience and knowledge could contribute to a more coordinated approach to food security.

\section{Conclusion}

This article contributes to the understanding of barriers faced by local government urban planners in addressing contemporary food security challenges in Victoria, Australia. This in-depth research, based on two state-local government partnership projects, highlights inadequacies in current legislative, policy, and regulatory systems and processes, and points to ways that urban planning can contribute to solving municipal food security problems. Residents need access to healthy food within walking distance from their homes, particularly in low socio-economic areas where car ownership and public transport is limited. Existing planning schemes enable walkability and cycling but seldom address issues related to food supply or food access. Local governments can only encourage the development or establishment of healthy food outlets in particular locations, as planning regulation does not enable influence on business mix. Case study participants found that local government planners were hesitant to push the boundaries of current planning schemes because they do not have the regulatory authority to insist that retail outlets include healthy food options.

Such a complex governance problem needs as many perspectives as possible to improve food system sustainability. While some barriers are internal to local government, such as in the UA regulatory environment, the systemic planning barriers shown in this research also demonstrate the problems of external fit with federal, and more significantly, state government policy and legislation, both of which limit local government planning capacity to respond. In a federal governance system, a complex problem such as food security requires attention at each level of government. Local government urban planners need increased legislative, policy, and regulatory tools to enable food security principles in land use decisions to facilitate municipal food security planning.
While this research identified roles for planning in addressing food security in the state of Victoria in Australia, future research could document and evaluate successful examples as well as barriers from other Australian states and around the world. Applied research could pilot and monitor new applications.

\section{Acknowledgements}

The authors sincerely thank the members and associates of the two food security programs who openly shared their food security work in this research, and the reviewers who have contributed to improving this article.

\section{References}

Alkon, A. H., Block, D., Moore, K., Gillis, C., DiNuccio, N., \& Chavez, N. (2013). Foodways of the urban poor. Geoforum, 48, 126-135. http://dx.doi.org/10.1016/i.geoforum.2013.04.021

Allender, S., Gleeson, E., Crammond, B., Sacks, G., Lawrence, M., Peeters, A., Loff, B., \& Swinburn, B. (2009). Moving beyond 'rates, roads and rubbish': How do local governments make choices about healthy public policy to prevent obesity? Australian and New Zealand Health Policy, 6(20), 1-8. http://dx.doi.org/10.1186/1743-8462-6-20

Aulich, C. (2005). Australia: Still a tale of Cinderella? In B. Denters \& L. E. Rose (Eds.), Comparing local governance: Trends and developments (pp. 193-210). Basingstoke, United Kingdom: Palgrave Macmillan.

Australian Institute of Health and Welfare (AIHW). (2012). Australia's food and nutrition 2012 (Cat no. PHE 163). Canberra, Australia: AIHW.

Ball, K., Timperio, A., \& Crawford, D. (2009). Neighbourhood socioeconomic inequalities in food access and affordability. Health \& Place, 15(2), 578585. http://dx.doi.org/10.1016/i.healthplace.2008. $\underline{09.010}$

Beer, C. (2013). Planning against hunger in a time of abundance: Scarcity, affluence, and food security within contemporary Australian urban planning. Australian Planner, 50(1), 35-43. http://dx.doi.org/10.1080/07293682.2012.700940

Booth, S., \& Smith, A. (2001). Food security and poverty in Australia-Challenges for dietitians. Australian Journal of Nutrition and Dietetics, 58(3), 150156. 
Budge, T., \& Slade, C. (2009). Integrating land use planning and community food security. Bendigo, Australia: La Trobe University.

Burns, C. (2004). A review of the literature describing the link between poverty, food insecurity and obesity with specific reference to Australia. Melbourne: Victorian Health Promotion Foundation.

Caspi, C. E., Sorensen, G., Subramanian, S. V., \& Kawachi, I. (2012). The local food environment and diet: A systematic review. Health \& Place, 18(5), 1172-1187. http://dx.doi.org/10.1016/i.health place.2012.05.006

Cassidy, A., \& Patterson, B. (2008). The planner's guide to the urban food system. Retrieved from http://www.cailg.org/sites/main/files/file-attachments/resources PlannersGuidetotheFoodSystem.pdf

Castillo, S. R., Winkle, C. R., Krauss, S., Turkewitz, A., Silva, C., \& Heinemann, E. S. (2013). Regulatory and other barriers to urban and peri-urban agriculture: A case study of urban planners and urban farmers from the greater Chicago metropolitan area. Journal of Agriculture, Food Systems, and Community Development, 3(3), 155-166. http://dx.doi.org/10.5304/jafscd.2013.033.001

City of Darebin. (2008). Food security in Darebin part 3: Mapping food supply and access. Melbourne, Australia: City of Darebin.

Clancy, K. (2004). Potential contributions of planning to community food systems. Journal of Planning Education and Research, 23(4), 435-438. http://dx.doi.org/10.1177/0739456X04264893

Cummins, S., \& Macintyre, S. (1999). The location of food stores in urban areas: A case study in Glasgow. British Food Journal, 101(7), 545-553. http://dx.doi.org/10.1108/00070709910279027

Cummins, S., \& Macintyre, S. (2005). Food environments and obesity-Neighbourhood or nation? International Journal of Epidemiology, 35(1), 100-104. http://dx.doi.org/10.1093/ije/dyi276

Department of Agriculture, Fisheries and Forestry (DAFF). (2011). Issues paper to inform development of a national food plan. Retrieved from http://trove.nla.gov.au/version/168203478

Department of Human Services, North \& West Metropolitan Region. (2008). Expression of interest process for regional funding for local government food access \& security policy development. Melbourne: Victoria.

Desjardins, E., Lubczynski, J., \& Xuereb, M. (2011).
Incorporating policies for a healthy food system into land use planning: The case of Waterloo Region, Canada. Journal of Agriculture, Food Systems, and Community Development, 2(1), 127-140. http://dx.doi.org/10.5304/jafscd.2011.021.003

Ding, D., \& Gebel, K. (2012). Built environment, physical activity, and obesity: What have we learned from reviewing the literature? Health \& Place, 18(1), 100-105. http://dx.doi.org/10.1016/j.healthplace. 2011.08.021

Donkin, A. J. M., Dowler, E. A., Stevenson, S. J., \& Turner, S. A. (1999). Mapping access to food at a local level, British Food Journal, 101(7), 554-564. http://dx.doi.org/10.1108/00070709910279054

Ghosh-Dastidar, B., Cohen, D., Hunter, G., Zenk, S. N., Huang, C., Beckman, R., \& Dubowitz, T. (2014). Distance to store, food prices, and obesity in urban food deserts. American Journal of Preventive Medicine, 47(5), 587-595. http://dx.doi.org/10.1016/j.amepre.2014.07.005

Girardet, H. (2004). Cities, people, planet: Livable cities for a sustainable world. Chichester, England: WileyAcademy.

Guy, C., Clarke, G., \& Eyre, H. (2004). Food retail change and the growth of food deserts: A case study of Cardiff. International Journal of Retail \& Distribution Management, 32(2), 72-88. http://dx.doi.org/10.1108/09590550410521752

Halloran, A., \& Magid, J. (2013). The role of local government in promoting sustainable urban agriculture in Dar es Salaam and Copenhagen. Geografisk Tidsskrift-Danish Journal of Geography, 113(2), 121-132. http://dx.doi.org/10.1080/00167223.2013.848612

Healey, P. (2005). On the project of 'institutional transformation' in the planning field: Commentary on the contributions. Planning Theory, 4(3), 301-310. http://dx.doi.org/10.1177/1473095205058498

Hobsons Bay City Council. (2011a). All food outlets, transport, major shopping areas map. Victoria, Australia: Hobsons Bay City Council.

Hobsons Bay City Council. (2011b). Access to nutritious food in Hobsons Bay: Areas of food deserts: Bakery, butcher, fruit \& vegetables map [Figure]. Victoria, Australia: Hobsons Bay City Council. Retrieved from http://www.hobsonsbay.vic.gov.au/files/6fead146d65c-429a-834b-a00e00ff2f60/FoodSecurityFact Sheet.pdf 
Kelly, B., Flood, V. M., \& Yeatman, H. (2011). Measuring local food environments: An overview of available methods and measures. Health \& Place, 17(6), 1284-1293. http://dx.doi.org/10.1016/j. healthplace.2011.08.014

Lang, T., Barling, D., \& Caraher, M. (2001). Food, social policy and the environment: Towards a new model. Social Policy \& Administration, 35(5), 538-558. http://dx.doi.org/10.1111/1467-9515.t01-1-00252

Levine, J. A. (2011). Poverty and obesity in the U.S. Diabetes, 60(11), 2667-2668. http://dx.doi.org/10.2337/db11-1118

Lockie, S., \& Pietsch, J. (2012). Public opinion on food security. Retrieved from http://lyceum.anu.edu. au/wp-content/blogs/3/uploads/Food Security_Poll.pdf

MacRae, R. (2011). A joined-up food policy for Canada. Journal of Hunger \& Environmental Nutrition, 6(4), 424-457.

http://dx.doi.org/10.1080/19320248.2011.627297

Mansfield, B., \& Mendes, W. (2013). Municipal food strategies and integrated approaches to urban agriculture: Exploring three cases from the global north. International Planning Studies, 18(1), 37-60. http://dx.doi.org/10.1080/13563475.2013.750942

Mendes, W. (2008). Implementing social and environmental policies in cities: The case of food policy in Vancouver, Canada. International Journal of Urban and Regional Research, 32(4), 942-967. http://dx.doi.org/10.1111/j.14682427.2008.00814.x

Morgan, K. (2009). Feeding the city: The challenge of urban food planning. International Planning Studies, 14(4), 341-348. http://dx.doi.org/10.1080/13563471003642852

Mougeot, L. J. A. (2006). Growing better cities: Urban agriculture for sustainable development. Ottawa, Canada: International Development Research Centre.

Nolan, M., Rikard-Bell, G., Mohsin, M., \& Williams, M. (2006). Food insecurity in three socially disadvantaged localities in Sydney, Australia. Health Promotion Journal of Australia, 17(3), 247-254.

Parham, S. (2007). Fat cities and food deserts: Exploring a socio-spatial continuum lesson for Australian cities from European experience. Retrieved from http://soac.fbe.unsw.edu.au/2007/SOAC/fatcities andfooddeserts.pdf
Pires, V., \& Burton, P. (2013). Help or hindrance? The relationship between land use planning and urban agriculture on the Gold Coast. In Q. FarmarBowers, V. Higgins \& J. Millar (Eds.), Food security in Australia: Challenges and prospects for the future (pp. 381-396). New York: Springer. http://dx.doi.org/10.1007/978-1-4614-4484-8 26

Port, C. M., \& Moos, M. (2014). Growing food in the suburbs: Estimating the land potential for suburban agriculture in Waterloo, Ontario. Planning Practice \& Research, 29(2), 152-170. http://dx.doi.org/10.1080/02697459.2014.896157

Pothukuchi, K., \& Kaufman, J. L. (2000). The food system: A stranger to the planning field. Journal of the American Planning Association, 66(2), 113-124. http://dx.doi.org/10.1080/01944360008976093

Prime Minister's Science, Engineering and Innovation Council (PMSEIC). (2010). Australia and food security in a changing world. Canberra, Australia: The Prime Minister's Science, Engineering and Innovation Council.

Reynolds, B. (2009). Feeding a world city: The London Food Strategy. International Planning Studies, 14(4), 417-424. http://dx.doi.org/10.1080/13563471003642910

Rosin, C., Stock, P., \& Campbell, H. (Eds.). (2012). Food systems failure. Oxfordshire, United Kingdom: Earthscan.

Sarantakos, S. (2005). Social research (3rd ed.). Hampshire, United Kingdom: Palgrave MacMillan.

Shannon, J. (2014). Food deserts: Governing obesity in the neoliberal city. Progress in Human Geography, 38(2), 248-266. http://dx.doi.org/10.1177/0309132513484378

Slade, C. (2012). Institutional capacity of local government to embed food security into policy. In Q. Farmar-Bowers, V. Higgins \& J. Millar (Eds.), Food security in Australia: Challenges and prospects for the future (pp. 63-77). New York: Springer. http://dx.doi.org/10.1007/978-1-4614-4484-8_5

Slade, C., \& Wardell-Johnson, A. (2016). Beyond governance of food systems: Planning for resilience in the Sunshine Coast, Queensland, Australia. In M. Kennedy, A. Butt \& M. Amati (Eds.), Conflict and change in Australia's peri-urban landscapes (pp. 221240). Abingdon, England: Routledge. 
Smith, S. J., \& Easterlow, D. (2005). The strange geography of health inequalities. Transactions of the Institute of British Geographers, 30(2), 173-190. http://dx.doi.org/10.1111/j.14755661.2005.00159.x

Sonnino, R. (2009). Feeding the city: Towards a new research and planning agenda. International Planning Studies, 14(4), 425-435. http://dx.doi.org/10.1080/13563471003642795

Stake, R. (2008). Qualitative case studies. In N. K. Denzin \& Y. Lincoln (Eds.), Strategies of qualitative inquiry (3rd ed., pp. 119-149). Thousand Oaks, California: SAGE.

Thibert, J. (2012). Making local planning work for urban agriculture in the North American context: A view from the ground. Journal of Planning Education and Research, 32(3), 349-357. http://dx.doi.org/10.1177/0739456X11431692

Thompson, S., Corkery, L., \& Judd, B. (2007). The role of community gardens in sustaining healthy communities. Retrieved from http://soac.fbe. unsw.edu.au/2007/SOAC/theroleofcommunity gardens.pdf

Turrell, G., Blakely, T., Patterson, C., \& Oldenburg, B. (2004). A multilevel analysis of socioeconomic (small area) differences in household food purchasing behaviour. Journal of Epidemiology \& Community Health, 58(3), 208-215. http://dx.doi.org/10.1136/jech.2003.011031

VicHealth. (2005). Healthy eating-Food security investment plan 2005-2010. Carlton, Victoria, Australia: VicHealth.

VicHealth. (2008). Food for All: How local government is improving access to nutritious food. Retrieved from https://www.vichealth.vic.gov.au/media-andresources/publications/how-local-government-isimproving-access-to-nutritious-food

VicHealth. (2010). Food for All-Resources for local governments. Retrieved from

https://www.vichealth.vic.gov.au/media-andresources/publications/food-for-all-resources-forlocal-governments

VicHealth. (2011). Food for All 2005-10 program evaluation report. Retrieved from https://www.vichealth.vic.gov.au/media-andresources/publications/food-for-all-2005-10program-evaluation-report

Walter, M. (Ed.). (2006). Social research methods: An Australian perspective. Oxford, United Kingdom: Oxford University Press.

Wheeler, S. M. (2004). Planning for sustainability: Creating livable, equitable, and ecological communities. New York: Routledge. http://dx.doi.org/10.4324/9780203300565

Winkler, E., Turrell, G., \& Patterson, C. (2006). Does living in a disadvantaged area entail limited opportunities to purchase fresh fruit and vegetables in terms of price, availability, and variety? Findings from the Brisbane Food Study. Health \& Place, 12(4), 741-748. http://dx.doi.org/10.1016/j.health place.2005.09.006

Yeatman, H. (2009). Action or inaction? Food and nutrition in Australian local governments. Public Health Nutrition, 12(9), 1399-1407. http://dx.doi.org/10.1017/S1368980008004114

Yin, R. K. (2003). Case study research: Design and methods (3rd ed.). Thousand Oaks, California: Sage Publications. 